\title{
Pembentukan Kelompok Usaha Bersama Perempuan Di Kelurahan Tuah Karya Kota Pekanbaru
}

\author{
NOVITA $^{1}$; KARTIKA SARI LUBIS ${ }^{2}$; RINA SUNDARI ${ }^{3}$ \\ Sekolah Tinggi Ilmu Ekonomi Riau \\ Jln. HR Soebrantas KM 12 Panam \\ E-mail : novita@ lecturer.stier.akbar.ac.id
}

\begin{abstract}
Joint Business Group is a group of citizens or socially built families formed by citizens or social assisted families who have been fostered through the Ministry of Social activities program to carry out social welfare activities and economic enterprises in a spirit of togetherness as a means to improve social welfare levels especially for women as added value for family income. The purpose of this community service is as an effort to accelerate the elimination of poverty through increasing the business capacity of members of the Joint Business Group which consist of women together in groups, increasing income, business development and increasing social awareness and solidarity among KUB members and surrounding communities. The service method applied is Formation, Guidance, Monitoring and Evaluation. Coaching is intended as an effort to improve the usability and results for the growth and development of KUB, in addition to increasing motivation and implementation capabilities in the field and the capacity of the management of KUB managers. Monitoring and Evaluation is carried out to determine the development of KUB and problems that are obstacles and efforts to solve them so that efforts to grow and develop KUB go according to plan.
\end{abstract}

Keywords: Joint Business Group

Kemiskinan adalah keadaan dimana terjadi ketidakmampuan untuk memenuhi kebutuhan dasar seperti makanan, pakaian, tempat berlindung, pendidikan, dan kesehatan. Kemiskinan merupakan masalah global, sebagian orang memahami dari istilah ini secara subyektif dan komparatif. Kondisi kehidupan masyarakat yang hidup dibawah garis kemiskinan dan selama ini belum banyak mendapat sentuhan dari kebijakan pemerintah dalam rangka meningkatkan kualitas hidupnya. Beberapa penyebab sehingga mereka diabaikan selama ini diantaranya karena alasan geografis yang terisolasi, budaya yang tertutup, membuat agen perubahan kurang tertarik melakukan pendekatan melalui pemberdayaan. Agar masyarakat menjadi produktif, diperlukan usaha-usaha. Usahausaha tersebut salah satunya adalah dengan memberdayakan masyarakat khususnya perempuan.

Proses peningkatan kesejahteraan masyarakat, dapat diterapkan berbagai pendekatan, salah satu diantaranya adalah pemberdayaan perempuan. Pendekatan pemberdayaan perempuan bukan hal yang sama sekali baru, tetapi sebagai strategi dalam pembangunan relatif belum terlalu lama di bicarakan. Memberdayakan masyarakat terkhusus perempuan adalah upaya memperkuat unsur-unsur keberdayaan itu untuk meningkatkan harkat dan martabat lapisan masyarakat yang berada dalam kondisi tidak mampu dengan mengandalkan kekuatannya sendiri sehingga dapat keluar dari perangkap kemiskinan dan keterbelakangan, atau proses memampukan dan memandirikan masyarakat (Kartasasmita, 1997:74) Strategi pengembangan perempuan, meliputi perhatian ditujukan untuk peningkatan kesejahteraan perempuan tergolong dalam kelompok masyarakat berpenghasilan rendah untuk mendapat kesempatan lebih besar dalam menuntut pendidikan pasca pendidikan dasar, mendorong makin ikut berperannya perempuan dalam mengembangkan dan 
memeanfaatkan kemajuan ilmu dan teknologi bagi pembangunan.

Langkah langkah pokok kebijakan tersebut, dilaksanakan melalui penyusunan rencana dan pelaksanaan program peningkatan kedudukan peranan perempuan secara lintas sektoral, menyusun program khusus yang diperuntukkan bagi perempuan, agar dapat mengejar ketertinggalannya dari kaum pria di berbagai bidang, meningkatkan kegiatan pendidikan bagi perempuan baik kegiatan sektoral maupun kegiatan khusus peranan perempuan, dan mengupayakan perluasan kesempatan kerja dan berusaha di sektor formal dan informal dengan meningkatkan pengetahuan, keterampilan, kesejahteraan dan produktivitas kerja serta peningkatan perlindungan kerja bagi perempuan (Achmad, 1992:51-52) Usaha meningkatkan ekonomi perempuan di Desa salah satunya dengan program pemberdayaan perempuan, pemerintah dalam hal ini membuat kebijakan berupa Program Pemberdayaan Fakir Miskin (P2FM) melalui pemberian dana hibah kepada Kelompok Usaha Bersama (KUB) yang didasari oleh Keputusan Menteri Sosial R.I. Nomor 84/HUK/1997 tentang Pelaksanaan Pemberian Bantuan Sosial Bagi Keluarga Fakir Miskin. Kehadiran program Kelompok Usaha Bersama (KUB) merupakan peluang yang berharga bagi wanita yang aktif dalam membangun dirinya sendiri dan lingkungannya dalam upaya mereka mencapai dan meningkatkan kesejahteraan keluarga mereka sendiri. Kondisi dan situasi ini memungkinkan mereka melakukan tindakan transformasi dalam berbagai upaya pencapaian kesejahteraan keluarga yang menyangkut dimensi fisik, ekonomi sosial, moral dan kultural di dalam perannya sebagai ibu rumah tangga dan pencari nafkah tambahan, mereka mampu mengubah lingkungannya dari lingkungan kehidupan sosial yang positif ke suasana kehidupan bermasyarakat yang aktif dinamis dan produktif, tindakan mereka ini bersumber pada makna nilai sosial budaya dan sosial ekonomi yang di wadahi dalam makna nilai agama Rifai dikutip oleh (Anwar, 2006:91).

Dengan melihat latar belakang masalah yang telah dikemukan di atas maka rumusan masalah dari pengabdian ini adalah: Proses pembentukan, pembinaan, monitoring dan evaluasi pengembangan sangat dipengaruhi oleh be rbagai faktor, bagaimana bantuan yang diberikan, bagaimana pendampingan yang dilakukan dan sebagainya

Dalam pengabdian pada masyarakat ini tim memberikan pemahaman dan membuat warga masyarakat khususnya perempuan: a) Masing-masing Anggota KUB mengerti membuat Laporan arus kas harian dan melakukan pemisahan dana antara dana usaha dengan dana rumah tangga (metode); b) Keterampilan membuat bentuk dan jasa produk yang standar melalui sistem peresepan terstandar Muncul merk produk yang mengikuti standar merk dagang dan kemasan yang baik (ada komposisi bahan, halal, pendaftaran POM dan Dinas Kesehatan serta no hp KUB).

Luaran yang diharapkan melalui kegiatan ini berkaitan dengan masalah menambah penghasilan rumah tangga adalah: Bagi warga masyarakat: terbentuknya warga masyarakat khususnya perempuan yang menghasilkan produk rumah tangga yang bernilai jual sebagai nilai tambah penghasilan bagi keluarga. Bagi lembaga perguruan tinggi: referensi bahan ajar dan artikel ilmiah

\section{METODE}

Dalam rangka pelaksanaan pengabdian pada masyarakat maka lokasi berada di Kota Pekanbaru yakni tepatnya di Perumahan Graha Bangun pada kelompok arisan silaturahmi. Sasaran dalam kegiatan ini adalah pedagang kaki lima, pedagang asongan dan juga penjual keliling.

Tahap persiapan yang dilakukan meliputi: Suroto dkk (2017). 
1. Survey lokasi

2. Pemantapan dan penentuan lokasi dan sasaran

3. Penyusunan bahan/materi pengabdian, yang meliputi: konsep dasar pembentukan KUB, persoalan yang dihadapi dan solusi yang diberikan.

Tahapan dalam pelaksanaan pengabdian dilakukan mempersiapkan antara lain:

1. Penjelasan tentang manfaat pembentukan KUB

2. Sesi pelatihan focus pada tata cara menghadapi berbagai persoalan yang dihadapi masyarakat khususnya perempuan

Untuk melaksanakan kegiatan tersebut digunakan beberapa metode pelatihan yaitu:

1. Metode ceramah: hal ini dipilih untuk memberikan penjelasan tentang konsep dasar dan manfaat dari pembentukan KUB perempuan.

2. Tanya jawab: metode ini digunakan untuk memahami berbagai persoalan yang dihadapi warga masyarakat dan memberikan solusi dan alternative solusi dari masalah yang dihadapi.

Dari 18 anggota kelompok arisan silaturahmi diundang sebanyak 16 warga yang hadir atau lebih dari $88,9 \%$ yang hadir pada kegiatan ini. Hal ini menandakan antusiasnya warga masyarakat dalam menghadiri kegiatan pengabdian ini demi mendapatkan pencerahan mengenai efisiensi pengeluaran rumah tangga dan menghadapi kondisi kehidupan yang ada.

Sebelum dilakukan kegiatan ini disebarkan kuesioner yang menjelaskan mengenai kondisi motivasi berprestasi mereka mulai dari konsep pengetahuannya, pemahamannya dan konsep praktek menghadapi masalah di lapangan. Dari peserta yang diajukan mencapai $37 \%$ yang memiliki pemahaman yang cukup dan sisanya memiliki pemahamannya rendah.

Setelah dilakukan pelatihan, hampir $82 \%$ peserta memahami dan mengerti dan tahu bagaimana cara mengatasi masalah dengan kondisi yang ada saat ini melalui berbagai kegiatan yang bersifat positif dan membangun. Hal ini menandakan keberhasilan dari pengabdian ini dilakukan.

\section{HASIL}

Berdasarkan hasil pengabdian yang dilaksanakan pada tanggal 25 Nopember 2018 lalu di kelompok usaha bersama Perumahan Graha Rawa Bangun kelurahan Tuah Karya Kota Pekanbaru tentang pementukan KUB, maka mengukur tingkat keberhasilan kegiatan yang telah dilaksanakan dengan cara melakukan evaluasi 2 (dua) tahapan yaitu sebelum (pretes) dan sesudah (pos tes).

Kegiatan evaluasi ini bertujuan untuk melihat seberapa jauh pengetahuan peserta pengabdian kepada masyarakat ini memahami tentang materi pelatihan yang diberikan. Indikator tingkat keberhasilan kehadiran peserta setelah disebarkan undangan dari 10 orang, yang hadir mencapai 9 orang dan hal ini mencapai 90\%. Kondisi ini dinilai berhasil karena target yang ditetapkan adalah hadir 50\% saja.

\section{PEMBAHASAN}

\section{Tingkat Pengetahuan peserta terhadap masalah yang dihadapi saat ini}

Sebagian besar dari jumlah peserta sudah memahami persoalan yang dihadapi saat ini dan kondisi ini dapat dilihat dari pencapaian dari grafik berikut ini:

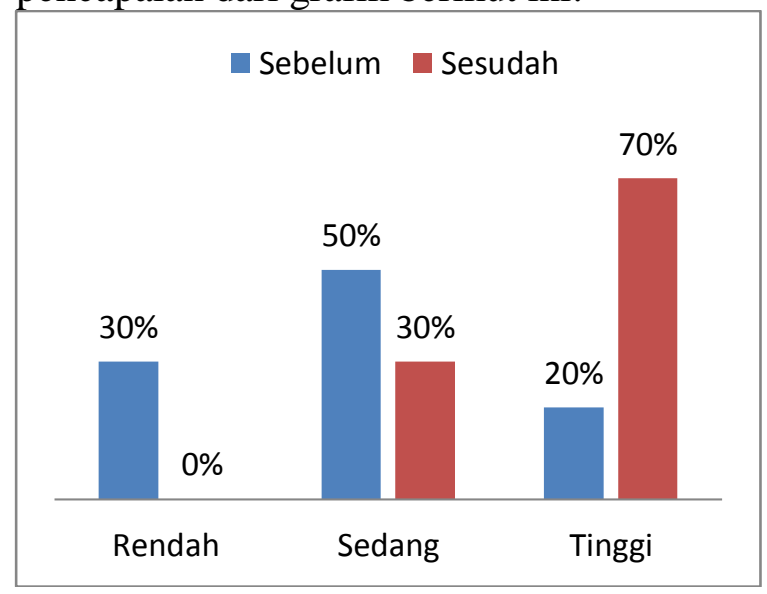

Dari gambar tersebut dapat dijelaskan bahwa sebelum mendapatkan pelatihan 
pengetahuan peserta terhadap masalah yang dihadapi masih rendah dan kemudian setelah mengikuti pelatihan pengetahuannya meningkat lebih tinggi, pengetahuan mereka tentang apa itu KUB dan maksud dan tujuan dari berdirinya KUB juga mereka sudah ketahui dengan baik, sehingga mereka bersemangat dalam mengikuti kegiatan tersebuit.

\section{Tingkat Pemahaman Peserta}

Tingkat pemahaman peserta dalam menjawab berbagai masalah yang dihadapinya antara lain:

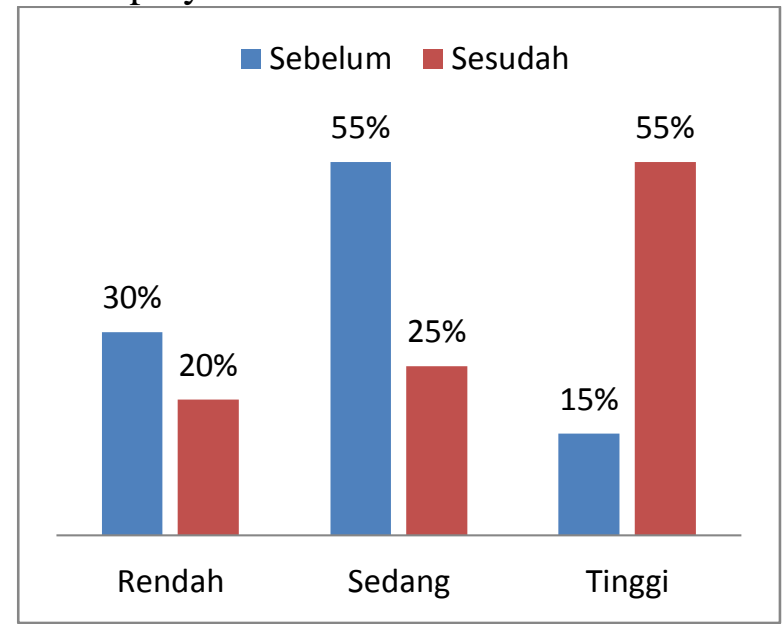

Dari data tersebut dapat dijelaskan bahwa setelah mengikuti pelatihan kemampuan peserta memahami konsep KUB dari sisi manfaat bagi mereak mengalami peningkatan yang cukup tinggi. Peserta mengetahui dengan baik manfaat yang akan dirasakan bagi peserta dalam mengikuti pelatihan tersebut dan ini menjadikan peserta semakin antusias dalam mengukuti pelatihannya.

Melalui pelatihan akan menjadikan usaha meningkatkan kemampuan dari para penerima pelatihan dalam pengembangan pengetahuannya. Rahman, F., \& Suroto, B. (2018).

\section{Tingkat Sikap Peserta}

Tingkat sikap peserta dalam berperan aktif mengikuti pelatihan yang dihadapinya antara lain:

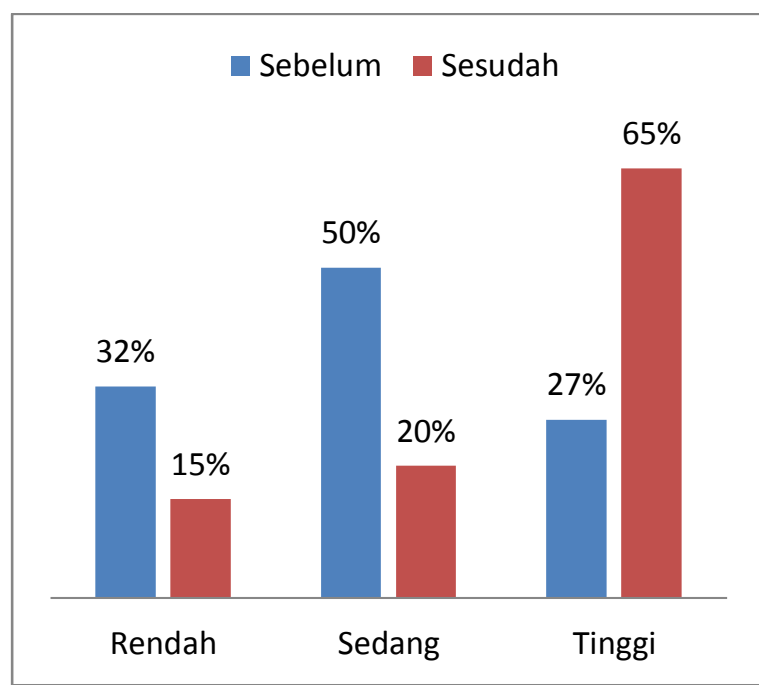

Dari data tersebut dapat bahwa peserta pelatihan dengan antusias mengikuti kegiatan pembentukan KUB setelah diterangkan kepada peserta semula kurang tertarik dan seterusnya mengalami peningkatan yang berarti.

\section{SIMPULAN}

Dari hasil pengabdian masyarakat yang dilaksanakan pada lokasi ini dengan mitra adalah kelompok usaha bersama graha permai. Sebelum dilakukan pelatihan mereka kurang memahami konsep dibentuknya KUB dan setelah mengikuti pelatihan pengetahuan, pemahaman dan sikap daripada peserta mengalami peningkatan yang berarti.

Berdasarkan dari kesimpulan di atas, maka diharapkan bagi para peserta pelatihan tertarik untuk bergabung dalam kelompok usaha bersama dan aktif membangun kegiatan dan program yang dibuat kelompok dalam rangka menumbuhkembangkan usaha yang ada sehingga mampu mandiri di masa depan. 


\section{DAFTAR RUJUKAN}

Arthur Keown J, David Scott F, Jhon Martin D, William Petty J, 2002, Dasar -. Dasar Manajemen Keuangan, Penerbit Salemba Empat

Suroto, B., Novita, N., Pailis, E. A., Waldelmi, I., \& Fatkhurahman, F. (2017). Metode Penelitian Tindakan Solusi Bagi Masalah Sosial. Jurnal Diklat Review, 1(1), 25-28.

Jong, De \& Den Hartog,. 2003. "Leadership as a determinant of innovative behavior". A Conceptual framework.

Rahman, F., \& Suroto, B. (2018). Model Pengembangan Kinerja Dosen Swasta (Studi pada Karyawan yang berprofesi sebagai Dosen). Human Sustainability Procedia.

Sutrisno, Edy. 2010. Manajemen Sumber Daya Manusia. Jakarta: Kencana 